\title{
The Children's Perceptions of the Teacher: An Analysis of the Drawings Created by the Children
}

\author{
Belgin Arslan Cansever \\ Ege University
}

\begin{abstract}
:
This study aims to determine how 66 and 68 months old children in the first grade of primary school perceive their teachers by their drawings. The study was carried out during the spring semester of 2015-2016 academic year. The research was based on the phenomenological design, a qualitative research method. Cluster sampling method, which is a randomization based sampling method, was used in this study. The research sample was composed of 152 first graders ( 80 boys and 72 girls) in Bornova, Izmir. The children were asked to draw the teacher in their imagination during one class period (40 minutes) while their teachers were present in the classroom. After the drawings completed, each student told the researcher what they drew. Drawings obtained within the scope of the study have been analyzed with Teacher Perception Coding List developed by Aykaç (2012). Most of the children illustrated their teachers as female, cheerful, clean and well-groomed. Besides, the children's gender did not make any significant differences in their teacher perception.
\end{abstract}

İnönü University

Journal of the Faculty of Education

Vol 18, No 1, 2017

pp. 281-291

DOI: 10.17679/inuefd.306625

Keywords: children's drawings, primary school, primary school teacher

Arslan Cansever, B. (2017). The Children's Perceptions of the Teacher: An Analysis of the Drawings Created by the Children, Inonu University Journal of the Faculty of Education, 18(1), 281-291. DOI: 10.17679/inuefd.306625 


\section{INTRODUCTION}

Education is a social process and the realization of this process, with a purposeful and systematic approach, is considered obligatory for society's sustainability. This obligation brings the formal side of the educational process to the forefront (Aslan, Aslan \& Arslan Cansever, 2012). Following pre-school educational institutions, the first step of formal education is primary school. The period of primary school is an important stage when the individual acquires knowledge on various subjects, skills, manner, and behavior. The quality of the education provided in primary school plays an important role in children's development. The quality of primary school is determined by the 'teacher' who assumes the role of developing the learning-teaching process with the physical structure and instruments in the school (Aykaç, 2012). Primary education is a brand-new environment for the child. Along with the basic knowledge and skills required for life, it aims to provide the child with a social identity, and supports creativity and productivity (Yavuzer, 2012). Primary education initiates the process of student life organization and provides the individual with the ability to collaborate with different people, and so prepares the student for life. In primary school, the child desires to belong to a community other than her/his family for the first time (Balcl, 1991). While the child develops this sense of belonging, s/he encounters a crucial figure at school that will leave deep impressions on her/his life: the primary school teacher.

\section{The role of the primary school teacher in a child's life}

A teacher, considered one of the basic and essential elements of formal education, brings specific knowledge and skill in the group of students $s /$ he addresses as well as shaping their attitude and behavior. Accordingly, the behavior and personality of the teacher is crucial for students and strongly impact them.

The teacher is the one who creates the psychological environment of the classroom by her personality traits, such as getting on well or not with her surrounding, making friends easily or not, being tolerant or criticizing everything, being aggressive or calm, being tough or easy with the students. Such personality traits of the teacher directly influence the students since the teacher is an adult model to be respected by the student. The educational environment is influenced by the personality and behavior of the teacher to a great extent (Aslan et al., 2012). The primary school teacher is the person who relays information on the subjects in the primary school curriculum, orientating them towards research, creativity, and assertiveness. The competent teacher helps them develop a positive attitude, and enables them to develop skills for effective communication with others. Such a teacher is one of the most important people in a child's life. This is because, primary school teachers are thought to be as models by students. Primary school teachers have a significant impact on children's personality development, behavior patterns and attitudes to any topic. Therefore, it is important to identify how students perceive their teachers in order to increase the quality of the educational process. According to Artut (2007), children naturally reflect their relationship with the teacher in their drawings. The technique of 'drawing' provides important data in the determination of this perception in childhood.

\section{Children's Drawings}

In a child's world, drawing is the language of expression by which s/he shares the thoughts and feelings coming from her/his inner world along with his perception of the outside world. In this context, analysis of drawings can be used as an effective technique to get to know the child. Drawings and children are of a complementary characters and among the most effective and important avenues of communication. It is accepted that children express their feelings, thoughts, and perceptions regarding their observations on events, situations, objects, and environment in general via drawing (Fury, Carlson \& Sroufe, 1997; Yavuzer, 2013). With this in mind, drawing is a way for children to express their entire interaction with the environment. Drawing, a more powerful tool of narration, expression, and reflection than the ability young children possess to express with words, is considered to be a reflection of the child's perception of his environment and human relationships. Researchers in this field (Cherney, Seiwert, Dickey \& Flichtbeil, 2006) emphasize the importance of encouraging children to draw in order to interpret their feelings, thoughts, and perceptions on a particular subject. It is a method that provides symbolic support for the natural reflection and expression of the feelings of their internal worlds and to reflect their relationships. Malchiodi (1998) suggests that the child needs to synthesize many components such as content, style, form, and composition and make an arrangement by choosing colors, forms, and lines. Children's drawings are considered to be a mirror of the narrative/symbolic development of the child. For young children, drawing is the language of thought expression (Cherney et al. 2006). 
Kehnemuyi (2009) refers to the age range of 4-7 as "pre-schematic period," when the first endeavors of mimesis are observed. The age of 5 (60 months), taken as the section and accepted to be the nodal point of early childhood development, is considered the golden age for the family and the child. The child at this age can use pencils and paint brushes skillfully, and attempts to express own feelings and thoughts. In this age, the child's favorite subject is the human figure and $s /$ he is able to draw a recognizable man with complete facial features. Most five-year olds can create purposeful drawings and include details in these drawings. They can name the drawings, explain them, and can paint the drawings carefully and skillfully without going out of the lines (Yavuzer, 2013). According to Linderman (1997), children learn by intuition at this age. They distinguish linear, diagonal, and curved lines and basic geometrical shapes such as a circle, triangle, and square, and incorporate them into their drawings. The size of the figures varies according to importance for the child. They draw not what they see but rather from their knowledge regarding an object or a person. They cannot perform proportional drawings of adults. They are curious about their environment and they benefit from their imagination in their drawings and start considering themselves as social beings. Malchiodi (1998) and Rodari (2007) state that in order to understand what the drawings of a children mean, the child's narration of the drawing needs to be listened to and interviews regarding their drawings need to be conducted.

Most "drawing" studies conducted thus far are from the perspective of the "scientist" (Buldu, 2006; Fort \& Vanney, 1989; Huber \& Burton, 1995; Kaya, Doğan \& Öcal, 2008; Korkmaz \& Kavak, 2010; Oğuz- Ünver, 2010; Rosenthal, 1993; Schibeci \& Sorensen, 1983). Several studies (Ahi, Cingi, \& Kıldan, 2016; Aykaç, 2012; Çam Aktaş, 2010; Harrison, Clarke, \& Ungerer, 2007) explores the perception of the teacher. This study was conducted with 66 and 68 months old first grade children in primary school. It is important to determine how younger age groups in the first grade of primary school perceive their teachers by examining the pictures they drew. The primary school teacher is a role-model for children and have significant role in the formation of their attitudes, behaviors and future educational life. In this sense, the question 'how do the children in the first grade of primary school perceive their teachers?' is the focus of the study. Subsequently, 'does the gender make a difference in their perception of the teacher?' is the sub-focus of the study.

\section{METHOD}

\section{Research Design}

In the research, analyses were based on the phenomenological approach within the qualitative research tradition have been made. In the phenomenological pattern, revelation and interpretation of the individual perceptions or points of view regarding a specific fact are sought (Yıldırım \& Şimşek, 2011). In the examination of children's drawings with this pattern, the context comprised by various meanings and the worldview of the drawer are emphasized (Malchiodi, 1998). Data can be the oral or written expressions of the participants as well as any other document that can indicate how they make sense of the events (Miles, \& Huberman, 1994). In this study, the ways of perception of primary school first grade students regarding the teacher have been attempted to be determined by their drawings and their narration of these drawings.

\section{Study Group}

Cluster sampling method, which is a randomization based sampling method, was used in this study. Cluster sampling is used when diverse groups are created naturally or artificially, but have similarities to each other (Yıldırım \& Şimşek, 2011: 105). The current school classes were regarded as clusters. Collecting data from students of a moderate socio-economic level was intended to obtain a sufficient representation of the subject, scope, limitations and time of the study. Five primary schools located in Bornova, Izmir were randomly selected. Study group covered 152 (80 boys, 72 girls) participants of first grade primary school, and focused on 66 and 68 months children due to an amendment to school age legislation enacted for the 2015-2016 academic year ${ }^{1}$.

\footnotetext{
1 Prior to the 2012-2013 school years, children in Turkey attended school for eight years, beginning at the age of seven (72 months). The Ministry of Education then shifted to 12 years of compulsory gradual education and this period was divided into three. First grade is defined as 4 years of primary school (1st, 2nd, 3rd, and 4th grade), second grade as 4 years of secondary school (5th, 6th, 7th, and 8th grade) and third grade as 4 years of high school (9th, 10th, 11th, and 12th grade), with children entering primary school at the age of five but lowering the age from seven to five initiated disputes in the educational environment and a new arrangement was made whereby children between 66 and 68 months were admitted based on their guardian's demand (MNE, 2012).
} 


\section{Research Procedure and Data Processing}

In the preliminary preparation stage of the study, interviews with primary school teachers and drawing teachers were conducted and, an agreement on using drawing pencils and paper was reached as a result of these interviews. In the pilot study, each student was given a drawing paper $25 \times 35 \mathrm{~cm}$ in size and drawing pencils, previously numbered in order to assist coding. Nine students who participated in this study were asked to 'draw the teacher in your imagination'. The completion of the drawings took approximately 35-40 minutes and then each student explained the researcher what they drew. This stage continued approximately $15-20$ seconds for every child.

The main study was conducted during a drawing class hour (40 minutes). As in the pilot study, the students were given a drawing paper $25 \times 35 \mathrm{~cm}$ in size, previously numbered, and no other guidance was proffered other than drawing a teacher themed picture. At the end of the given time, the drawings were collected by the researcher and then each student told the researcher what they drew. The researcher took notes of what the children narrated, and the drawings scanned onto a computer after the drawing session.

\section{Data Analysis}

In the analysis of the drawings obtained within the scope of the study, the Teacher Perception Coding List prepared by Aykaç (2012) was used. The categories in the Teacher Perception Coding List have been defined as 'type', 'gender', 'size', 'gesture and mimics', 'physical characteristics', 'location', 'activity performed', 'the object in hand', 'imagery', and 'the objects in classroom' (p. 303). Aykaç (2012) prepared 13 categories similarly to the 'Draw A Scientist Test- DAST' of Chambers (1983) and 'Draw A Scientist TestChecklist - DAST-C' developed by Finson and Beaver (1995). The elements encountered in the drawings were evaluated within the framework of the categories taken from Aykaç (2012). Drawings of the students were analyzed and interpreted by researcher according to the frequency (f) and percentages (\%) obtained within the framework of these categories.

\section{Validity and Reliability Measures}

This study's validity was ensured by consulting expert opinions in the planning, conducting and evaluative processes. The processes were explained in detail, and the results included children's drawings. To ensure the reliability, the children's drawings were directly presented in the study and findings and results were continuously checked. The researcher and the two experts in evaluating children's drawings examined the encodings of the children's drawings. Agreement and disagreements associated with these codings were determined. In addition, the drawings used for data analysis were kept, their analysis were explained in detail, and the researcher tried to obtain objective results by avoiding subjectiveness throughout the research. The researcher attempted to present results of the study in a clear and comprehensible way.

\section{FINDINGS}

The findings of the study were presented based on themes of the 'Teacher Perception Coding List' developed by Aykaç (2012). These themes were gender, physical appearance, gestures and facial expressions, physical characteristics, size, action type, objects in the hand and were presented on tables with descriptive (frequency and percentage) statistics.

\section{Gender of the teacher in children's drawings}

This study examined gender distribution of teachers in children's drawings and its findings are shown in Table 1.

Table 1

Gender of the teacher

\begin{tabular}{lllll}
\hline & \multicolumn{2}{c}{ Girls } & \multicolumn{2}{c}{ Boys } \\
\cline { 2 - 5 } Female & $f$ & $\%$ & $f$ & $\%$ \\
Male & 67 & 93.1 & 52 & 65.0 \\
Indefinite & 4 & 5.5 & 27 & 33.75 \\
Not human & - & - & 1 & 1.25 \\
\hline Total & 1 & 1.4 & - & - \\
\hline
\end{tabular}

In examining Table 1, it is found that $93.1 \%$ of girls and $65.0 \%$ of boys drew their teacher as 'female'. In their drawings, girls mostly drew their teachers as the same gender as themselves. According to this 
finding, it can be said that the gender of the teacher is mostly perceived as 'female' by the children. The pictures 1 and 2 below reflect the drawings of the children regarding the subject:

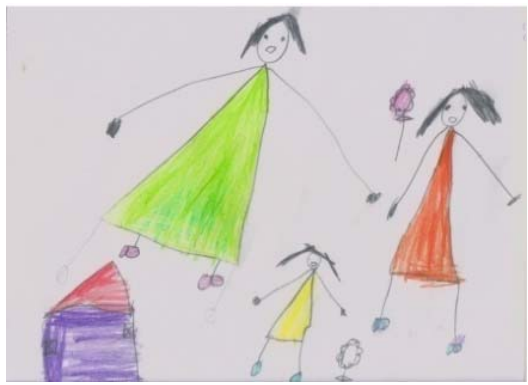

Picture:1, code:53, boy

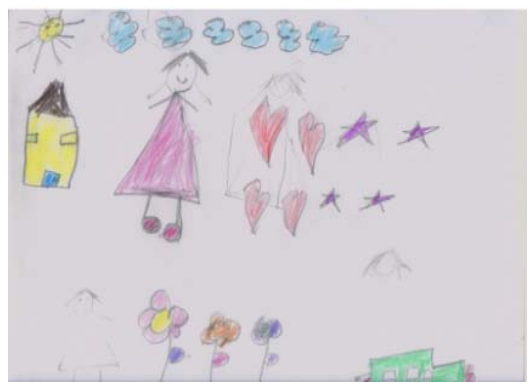

Picture:2, code:69, girl

\section{Physical appearance of the teacher in children's drawings}

This study examined physical appearance of the teacher in children's drawings as in Table 2.

Table 2

Physical appearance of the teacher

\begin{tabular}{lllll}
\hline & \multicolumn{3}{c}{ Boys } \\
\cline { 2 - 5 } & $f$ & $\%$ & $f$ & $\%$ \\
Dress/skirt & 60 & 83.2 & 60 & 75.0 \\
Suit & 7 & 9.8 & 17 & 21.25 \\
Messy & - & - & 1 & 1.25 \\
Tie & 2 & 2.8 & - & - \\
Sweat suit & - & - & 1 & 1.25 \\
Young & 1 & 1.4 & - & - \\
In white coat & 1 & 1.4 & - & - \\
Not pictured & - & - & 1 & 1.25 \\
Other & 1 & 1.4 & - & - \\
\hline Total & 72 & 100 & 80 & 100 \\
\hline
\end{tabular}

Findings show that $83.2 \%$ of the girls and $75.0 \%$ of the boys drew their teacher in 'dress' and 'skirt'.

Pictures 3 and 4 indicate the drawings of two different children describing their teachers in dress and skirt.

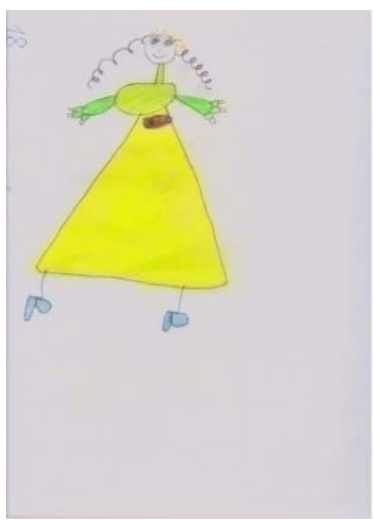

Picture:3, code:27, boy

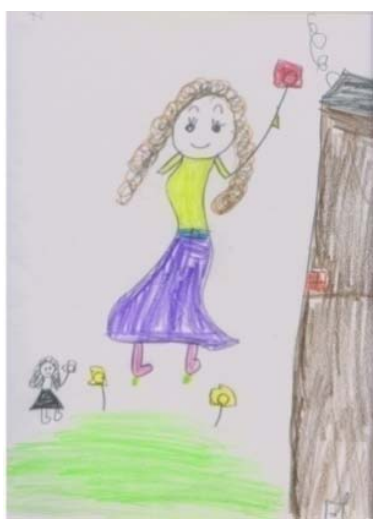

Picture:4, code:14, girl

\section{Gestures and facial expressions of the teacher in children's drawings}

Gestures and facial expressions of the teacher in children's drawings are shown in Table 3.

Table 3

Gestures and facial expressions of the teacher

\begin{tabular}{llll}
\multicolumn{2}{c}{ Girls } & \multicolumn{2}{c}{ Boys } \\
\hline$f$ & $\%$ & $f$ & $\%$
\end{tabular}




\begin{tabular}{lllll} 
Not pictured & - & - & 1 & 1.25 \\
Angry & - & - & 1 & 1.25 \\
Cheerful & 69 & 95.8 & 73 & 91.25 \\
Excited & 1 & 1.4 & - & - \\
Bewildered & - & - & 1 & 1.25 \\
Sad & 1 & 1.4 & - & - \\
Shy & 1 & 1.4 & - & - \\
Worried & - & - & 1 & 1.25 \\
Happy & - & - & 1 & 1.25 \\
Unhappy & - & - & 1 & 1.25 \\
Thoughtful & - & - & 1 & 100 \\
\hline Total & 72 & 100 & 80 & 100 \\
\hline
\end{tabular}

According to Table 3, a large ratio of the children (girls: $95.8 \%$; boys: 91.25 ) drew their teachers as cheerful. Findings indicate that the teachers are perceived as 'cheerful' by the students. This can be considered 'positive' in terms of children's teacher perception. The results did not vary by gender. Pictures 5 and 6 below indicate two drawings of cheerful teachers:

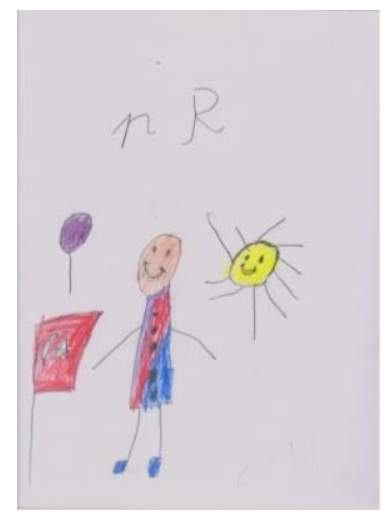

Picture:5, code:6, boy

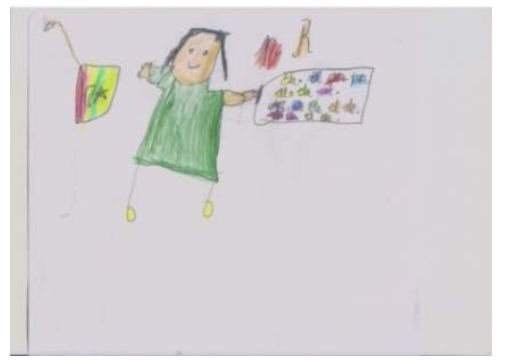

Picture:6, code:35, girl

\section{Physical Characteristics of the teacher in children's drawings}

This study examined the physical characteristics of the teacher, and the findings are shown in Table 4.

Table 4

Physical characteristics of the teacher

\begin{tabular}{|c|c|c|c|c|}
\hline & Girls & & & \\
\hline & $f$ & $\%$ & $f$ & $\%$ \\
\hline Not pictured & 3 & 4.2 & 7 & 8.75 \\
\hline Wearing glasses & 12 & 16.6 & 16 & 20.0 \\
\hline Clean and well-groomed & 53 & 73.6 & 54 & 67.5 \\
\hline Messy hair & 1 & 1.4 & - & - \\
\hline Bold & 2 & 2.8 & - & - \\
\hline Bearded & - & - & 1 & 1.25 \\
\hline Moustache & - & - & 1 & 1.25 \\
\hline Physically disabled & 1 & 1.4 & - & - \\
\hline Remarkable scars & - & - & 1 & 1.25 \\
\hline Total & 72 & 100 & 80 & 100 \\
\hline
\end{tabular}

According to Table 4, children drew the physical characteristics of the teacher as 'clean and well-groomed' (girls: $73.6 \%$; boys: $67.5 \%$ ) and 'wearing glasses' (girls: $16.6 \%$; boys: $20.0 \%$ ). The findings show that the physical properties of the teachers were depicted in similar ways at similar ratios by students of both genders. Picture number 7 indicates a clean, well-groomed teacher wearing glasses: 


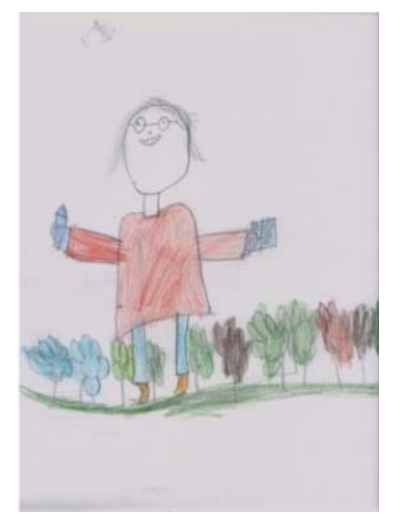

Picture:7, code:4, boy

\section{Size of the teacher in children's drawings}

Findings regarding size of the teacher are shown in Table 5.

Table 5

Size of the teacher figure

\begin{tabular}{lllll}
\hline & \multicolumn{2}{c}{ Girls } & \multicolumn{2}{c}{ Boys } \\
\cline { 2 - 5 } Bigger than actual & $f$ & $\%$ & $f$ & $\%$ \\
Smaller than actual & 57 & 79.2 & 47 & 58.75 \\
Realistic & 4 & 5.5 & 15 & 18.75 \\
\hline Total & 11 & 15.3 & 18 & 22.5 \\
\hline
\end{tabular}

Table 5 indicates the size of the teacher's figure according to the children's perception. In this context, both girls (79.2 \%) and boys (58.75 \%) pictured their teachers bigger than actual. More girls than boys drew their teachers bigger than actual. Drawings 8 and 9 below represent teachers as bigger than actual.

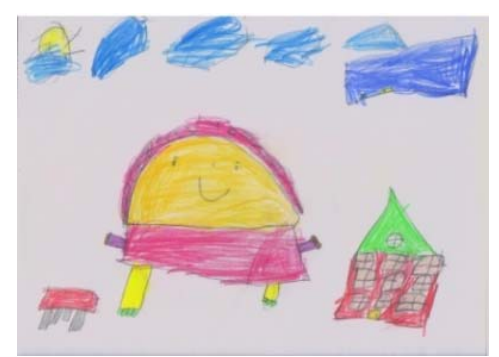

Picture:8, code:44, boy

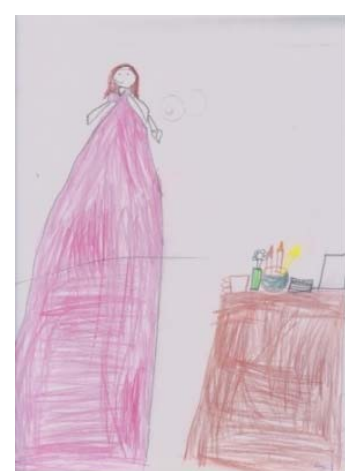

Picture:9, code:18, girl

\section{Actions of the teacher in children's drawings}

This study examined actions of the teacher, and its findings are shown in Table 6.

Table 6

Actions of the teacher

\begin{tabular}{lllll} 
& \multicolumn{3}{c}{ Girls } & \multicolumn{1}{c}{ Boys } \\
\cline { 2 - 5 } Not pictured & $f$ & $\%$ & $f$ & $\%$ \\
Writing on the board & 1 & 1.4 & - & - \\
Lecturing & 17 & 23.6 & 20 & 25.0 \\
Standing & 30 & 41.6 & 51 & 63.75 \\
Walking around the classroom & 7 & 9.7 & 3 & 3.75 \\
Talking to the students & 12 & 16.7 & 3 & 3.75 \\
Distributing school reports & 2 & 2.8 & - & - \\
Conducting an experiment & - & - & 1 & 1.25 \\
\hline
\end{tabular}




\begin{tabular}{lllll}
\hline Caressing the students & 1 & 1.4 & - & - \\
Taking Flowers & 1 & 1.4 & - & - \\
Playing with the students & - & - & 2 & 2.50 \\
\hline Total & 72 & 100 & 80 & 100 \\
\hline
\end{tabular}

According to Table 6, which indicates actions of the teacher, the girls (41.6\%) and the boys (63.75\%) drew their teacher 'lecturing'. Findings indicate that the students drew their teacher 'someone relaying transmitting knowledge'. In Picture 10, a teacher lecturing in front of the board is drawn:

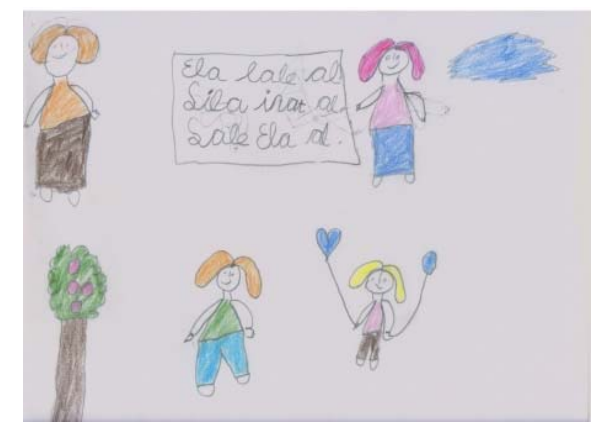

Picture:10, code:78, boy

Objects in the teacher's hand in children's drawings

Table 7 shows findings regarding children's perceptions of objects that teachers hold.

Table 7

Objects in the teacher's hand

\begin{tabular}{lllll}
\hline & \multicolumn{2}{c}{ Girls } & \multicolumn{2}{c}{ Boys } \\
\cline { 2 - 5 } Not pictured & $f$ & $\%$ & $f$ & $\%$ \\
Board marker & 5 & 6.9 & 3 & 3.75 \\
Book & 36 & 50.0 & 46 & 57.5 \\
Purse & 20 & 27.8 & 12 & 15.0 \\
Ruler-Stick & 7 & 9.7 & 16 & 20.0 \\
Chalk & 1 & 1.4 & 1 & 1.25 \\
Paper & 1 & 1.4 & - & - \\
Flower & - & - & 1 & 1.25 \\
\hline Total & 2 & 2.8 & 1 & 1.25 \\
\hline
\end{tabular}

Table 7 indicates the objects in the teacher's hand and supports Table 6 . Girls (50.0\%) and the boys (57.5\%) drew their teachers while writing something on the board with a board marker in his/her hand. This did not vary by gender. In a similar way to Table 6, students identified their teacher, whom they see as having assumed the 'role of transmitting knowledge', by writing on the board with a marker. Pictures 11 and 12 given below indicate two teachers performing sentence practice with a marker in their hand.

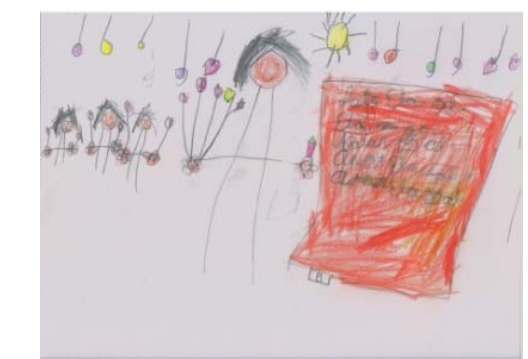

Picture:11, code:61, boy

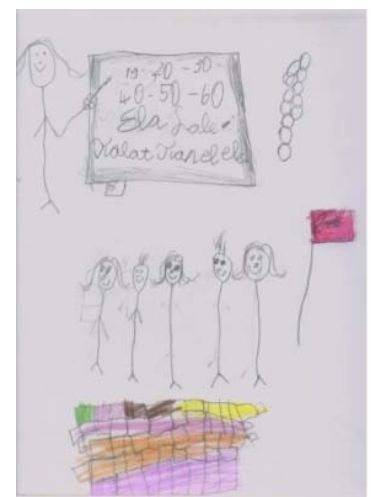

Picture:12, code:2, girl 


\section{DISCUSSION, RESULT AND RECOMMENDATIONS}

This study aims to determine how 66 and 68 months old children in the first grade of primary school perceive their teachers by their drawings. In the data obtained in this research, both girls and boys portrayed their teachers as 'female'. It can be said that, in general, children perceive the gender of the teacher as 'female'. Being parallel with the findings of this study, Aykaç (2012) found that $62 \%$ of the students drew the teacher as 'female'. Similarly, Kesicioğlu and Deniz (2014) determined that 49,2\% of the students drew the teacher as 'female'. These results can be attributed to the fact that the roles of teachers in terms of gender are more appropriate for women. At the same time, it can be said that having a large number of female teachers in schools affect children's perceptions. Thus according to recent studies conducted in the USA (Ingersoll, Merrill \& May, 2012), the ratio of women in the teaching labor force has been increasing. From the data of OECD's (2012) "Ratio of female teachers based on educational levels" in different countries, it has been ascertained that at primary school level, in almost all of the OECD countries, the ratio of female teachers is higher than that of male teachers. For example, the ratio of females in Estonia, Slovakia, and Israel along with Slovenia, Hungary, Italy, Brazil, Czech Republic, USA, Austria, and Germany is higher than the OECD average of $82 \%$. According to this data, the ratio of female teachers at the primary school level is $52.0 \%$. In developed countries, education has always been a traditional branch of occupations and is considered opportune for women who want to have both family and a career (UNESCO, 2012). In a comparison made between the years 1991-2004, this ratio increased in many countries; while the worldwide ratio of female teachers in primary education was 56 percent in 1991, it increased to 61 percent in 2004 (UNESCO, 2006). All the statistical information indicate that the teaching profession is chosen by females more than males. This is a common fact especially in primary schools. This also affects society's general perception of gender in the teaching profession, and so, teaching has been associated with the female gender.

It was found that both girls and boys drew their teachers most often in skirts or dresses. This is similar to the results of the studies conducted by Aykaç (2012), and Ahi, Cingi and Kıldan (2016). It can be explained by the acquisition of gender roles in the socialization process. The reason why children drew teachers in skirts and dresses is that the individual's knowledge of gender roles (clothing style, speaking style, etc.) transmitted them by gender socialization. Giddens (2009) explained socialization as the acquisition of information that is valid for the society in which children are born, while Tezcan (1999) emphasized the internalization of social behavior patterns in this process. Furthermore, Doğan (2011) regarded socialization as an individual's participation in the common life of a society by learning cultural norms, values and other aspects of social life, and according to Mora (2005), it involves the learning of social roles and gender roles. First, families and intimate environments, then peer groups, school and mass media play an effective role in socialization process. In schools, textbooks convey explicit and implicit messages to children while they acquire and learn social gender roles (Tietz, 2007). Implicit messages are subtexts in texts, such as manner of dress and activities represented in images. In images, the female figures are frequently represented in skirts and dresses. Children encountering texts and images based on this gender difference learn the roles of different genders and their physical appearances.

In this study, children generally described their teachers' gestures and facial expressions 'cheerful'. This did not vary by gender. As stated by Aslan et al. (2012), the basic attitude and behavior, and the emotional status of the teacher leave either a negative or positive impact on the student. With reference to this information, it can be inferred that children perceive their teachers 'positively'.

Children described the physical appearance of their teachers 'clean and well-groomed' in general. This finding obtained from the study overlaps the result of the study of Aykaç (2012). Children perceive the physical appearance of teachers in a positive way. This indicates that teachers are positively perceived by students in terms of physical appearance.

Most of boys and girls drew their teachers bigger than actual. Yavuzer (2013) stated that, in some cases, children may draw teachers bigger than actual or out of proportion because of their admiration for them. According to Payne (1990), children tend to draw people who they deem to be strong, in bigger size. 'Bigger than actual' aspect that emerged in this study illustrates a positive value.

In the research, children drew their teachers lecturing in front of the board with a board marker in their hand. This indicates that the students perceive their teacher as 'someone relaying information'. The 
findings of this study largely agree with those of Çam Aktaş (2010) and Aykaç (2012). In both studies, students drew teachers teaching lessons in front of the board. Drawing teachers teaching has been associated a positive atmosphere in schools and classroom environments by Birch and Ladd (1997). Thus, the present study regarded the fact that children drew their teachers teaching lessons in front of the board as positive.

Children's social and natural environments affect their perceptions of the world as a living space. For instance, in a study where the pattern judgments of people living in Turkey regarding different occupations were surveyed, 1161 participants made the most positive attributions to the occupation of teaching (7.1\%). Participants found teachers as trustworthy (28.0\%) and hardworking (20.1\%) (Tutkun \& Koç, 2008). Thus, it can be inferred that the positive perception of primary age children about teachers is influenced by their social and natural environment. Consequently, it can be said that both boys and girls view teachers 'positively'. This positive teacher perception developed in primary school can enable the child to continue his educational with more positive feelings. Teachers effect the attitudes and behaviors of students in besides transmitting knowledge. Individuals' inner peace and capability of building effective communication with others depend on the success of the primary education provided for them. Thus, classroom teachers should be the role models for students, and guide them with their knowledge and personality.

This research is limited to the drawings created by the participants as well as their socio-cultural characteristics, and the analysis technique adopted for analysis. In this study, children may be effected by their teachers being present in the classroom during the process of their drawings. Further studies should have children draw when their teachers are not in the classroom. There are limited number of studies in the literature about perceptions of teachers in the early grades of primary school. In future studies, it may be useful to conduct research in different stages to determine teacher perception through drawings with larger sample sizes. Data diversity can be conducted in studies where the researcher(s) monitor classroom environments as participant-observer(s), in-depth interviews with children and drawing as a data collection tool.

\section{REFERENCES}

Ahi, B., Cingi, M. A., \& Kıldan, A. O. (2016). 48-60 Aylık çocukların öğretmen kavramına yönelik algılarının çizimler aracılığıyla incelenmesi. Elementary Education Online, 15(1), 77-90.

Artut, K. (2007). Okuloncesinde resim eğitimi. (2nd ed.). Ankara: Anı Yayıncılık.

Aslan, K., Aslan, N., \& Arslan-Cansever, B. (2012). Eğitim bilimine giriş. Ankara: Pegem Akademi.

Aykaç, N. (2012). İlköğretim öğrencilerinin resimlerinde öğretmen ve öğrenme süreci algısı. Egitim ve Bilim, (37) $164,298-315$.

Birch, S. H. \& Ladd, G. W. (1997). The teacher-child relationship and children's early school adjustment. Journal of School Pschology, 35(1), 65-79.

Buldu, M. (2006). Young children's perceptions of scientists: A preliminary study. Educational Research, $48(1), 121-132$.

Balci, E. (1991). Öğretmenlerin rolleri. Egitim Sosyolojisi, Ankara.

Çam Aktaş, B. (2010). Investigating primary school students' perceptions regarding 'teacher' through their drawings. The International Journal of Learning, 17(8), 409-425.

Cherney, I. D., Seiwert, C. S., Dickey, T. M., \& Flichtbeil, J. D. (2006). Children's drawings: a mirror to their minds. Educational Psychology, 26(1), 127-142.

Doğan, ì. (2011). Eğitim sosyolojisi. Ankara: Nobel Akademi.

Fort, D. C. \& Vanny, H. L. (1989). How students see scientists: Mostly male, mostly white, and mostly benevolent. Science and Children, 26 (8), 8-13.

Fury, G.; Carlson, E. A., \& Sroufe, L. A. (1997). Children's representations of attachment relationships in family drawings. Child Development, 68, 1154-1164.

Giddens, A. (2009). Sociology. ( 6th ed.). Cambridge: Polity Press.

Harrison, L. J., Clarke, L., \& Ungerer, J. A. (2007). Children's drawings provide a new perpective on teacherchild relationship quality and school adjustment. Early Childhood Research Quaterly, 22(1), 55-71.

Huber, R. A. \& Burton, G. M. (1995). What do students think scientists look like? School Science and Mathematics, 95(7), 371-377.

Ingersoll, R. M., Merrill, L., \& May, H. (2012). Retaining teachers: How preparation matters. Educational Leadership, 69(8), 30-34. 
Kaya, O. N., Doğan, A., \& Öcal, E. (2008). Turkish elementary school students' images of scientists. Egitim Arastirmalari-Eurasian Journal of Educational Research, 32, 83-100.

Kehnemuyi, Z. (2009). Çocuğun görsel sanat eğitimi. (6th ed.), İstanbul: Yapı Kredi Yayınları.

Kesicioğlu, O. S. \& Deniz, Ü. (2014). Investigation of pre-school children's perception of teacher in their drawings. Creative Education, 5, 606- 613.

Korkmaz, H. \& Kavak, G. (2010). Primary school students' images of science and scientists. Elementary Education Online, 9(3), 1055-1079.

Linderman, M. G. (1997). Art in the elemantary school. United States: The McGraw-Hill Companies, Inc.

Malchiodi, C. A. (1998). Understanding children's drawings. New York: The Guilford Press.

Ministry of National Education (Milli Eğitim Bakanlığı) (2012). Erişim tarihi: 24.03.2016, http://www.meb.gov.tr/haberler/2012/12YillikZorunluEgitimeYonelikGenelge.pdf.

Miles, M. B. \& Huberman, A. M. (1994). Qualitative data analysis: An expanded sourcebook. Thousand Oaks, CA: Sage Publications.

Mora, N. (2005). Kitle iletişim araçlarında yeniden üretilen cinsiyetçilik ve toplumda yansıması. Uluslararası Insan Bilimleri Dergisi, 2 (1), 1-7.

Oğuz- Ünver, A. (2010). Perceptions of scientists: A comparative study of fifth graders and fourth year student teachers. Necatibey Faculty of Education Electronic Journal of Science and Mathematics Education, 4(1), 11-28.

Payne, M. A. (1990). Effects on parental presence /absence on size of children's human figure drawings. Perceptual and Motor Skills, 70, 843-849.

Rodari, P. (2007). Science and scientist in the drawings of European children. Journal of Science Communication, 6(3), 1-12.

Rosenthal, D. B. (1993). Images of scientists: A comparison of biology and liberal studies majors. School Science and Mathematics, 93(4), 212-216.

Schibeci, R. A. \& Sorensen, I. (1983). Elementary school children's perceptions of scientists. School of Science and Mathematics, 83(1), 14-19.

Tezcan, M. (1999). Eğitim sosyolojisi, Ankara: Şafak Matbaacılık.

Tietz, W. M. (2007). Women and men in accounting textbooks: exploring the hidden curriculum. Issues in Accounting Education, 22 (3), 459-480.

Tutkun, O. F. \& Koç. M. (2008). Mesleklere atfedilen kalıp yargılar. Ankara Üniversitesi Eğitim Bilimleri Dergisi, Cilt: 41, Sayı:1, 255-273.

UNESCO. (2006). Teachers and educational quality: monitoring global needs for 2015. Montreal: UNESCO Institute for Statistics.

UNESCO. (2012). UNESCO strategy on teachers (2012- -2015). Erişim tarihi: 21.03.2016, http://unesdoc.unesco.org/images/0021/002177/217775e.pdf.

Yavuzer, H. (2012). Çocuğunuzun ilk 6 yılı. (28th ed.) İstanbul: Remzi Kitabevi.

Yavuzer, H. (2013). Resimleriyle çocuk. İstanbul: Remzi Kitabevi.

Yıldırım, A. \& Şimsek, H. (2011). Sosyal bilimlerde nitel araştırma yöntemleri. (6. baskı.), Ankara: Seçkin Yayınları. 